\title{
Study of protein metabolism of Gallus gallus domesticus (Linn, 1758) infected by Raillietina (Eucestoda)
}

\author{
Waghmare S.B., Gomase V.S.* and Chavan R.J. \\ Helminthes Research Lab, Department of Zoology, Dr. B.A.M.Universuty, Aurangabad, \\ sachinash_red@yahoo.co.in \\ *School of Technology, S.R.T.M.University, Sub Center, Latur
}

\begin{abstract}
The values and dynamics of some indices of protein metabolism were studied in domestic bird Gallus gallus domesticus infected with cestodes Railletina echinobothrida, (Magnin, 1881) in natural population and in experiment. These indices were compared in infected and non- infected birds. Cestode infection considerably affected hosts protein metabolism irrespective of the age; however the chances were more pronounced in younger ones. Increased concentration of $y$-globulin, modified albumin and circulating immune complexes was observed in plasma of infected host. The experiment demonstrated the most significant changes in the protein metabolism of Gallus gallus domesticus 4- 8 days after infestation with cestodes Railletina echinobothrida (Magnin, 1881).
\end{abstract}

Key words-Protein metabolism, Gallus gallus domesticus, Railletina echinobothrida, Globulins

\section{Introduction}

In animal husbandry now a day's farmer reared the Gallus gallus domesticus bird for allied business but due to parasitic infection birds are not well developed. Many problems of helminth impact on the body of animal host in natural population remain unstudied. This is also true for the domesticated bird gallus. Some negative impact of parasites on their host is assumed a prior; however little valid data available on its physiological mechanism. There are various workers who work on the impact of helminth on host organism (Pronina and Pronin, 1988, Kuklina and V.V.Kuklin, 2007, Silkina and Mikryakov, 2005a, 2005b, etc.). Little valid data are available on the impact of helminth parasitic worms on the body of domestic bird under natural condition. Aim of the present study is impact of infection with cestode Railletina echinobothrida, Magnin, 1881 on some indices of protein metabolism is Gallus gallus domesticus, under natural and experimental condition.

\section{Material and Methods}

The material was collected from the local area of Aurangabad Marathwada region of state Maharashtra (India) in Dec.2006- Dec.2009. In total 78 gallus birds were studied including 45 mature and 33 juvenile birds. Cestode Railletina echinobothrida, Magnin, 1881 complete development largely in Gallus gallus domesticus (incidence of infestation 66.65 and prevalence 72.50). Experimental studies were carried out at the Helminth Research Lab., Dept. of Zoology, Dr. Babasaheb Ambedkar Marathwada University, Aurangabad Maharashtra (India). Nestling of Gallus were collected on neighboring area of city. The experiment lasted 28 day. In first two weeks birds were hand reared and dewormed (Piperazine and albendazole) (Pubinina 1950, Krotov, 1970). Experimental nesting was infected by experimental day 14 by feeding eggs of with $12,15,21,24$, or 30 infective metacercariae of Raillietina. Eggs were collected in the rural zone of area birds were feed the same twice a day. Blood plasma of birds was used for the biochemical tests. Blood was taken from experimental nestling one day prior to infestation and after $4,8,11$, and 14 day while single blood samples were taken in the study of the natural bird population. Blood was collected into sodium heparin tubes and plasma was separated by centrifugation at $3000 \mathrm{rpm}$ for 20 min. The plasma sample was frozen until laboratory analysis. Protein concentration was determined by Biuret assay. While the content of protein fraction was determined by electrophoresis in paper (Kamyshnikov, 2000). Level of modified albumin was determined by the method of Troijkii (1986) circulating immune complexes (CIC's) were assayed by polyethylene glycol precipitation. The alaine amino transferase (ALT) and aspartate amino transferase (AST) activities were determined by method of Reitman's and Frankel (Kamyshnikov, 2000). At the time of blood withdrawal gallus bird were also studied for the parasitological analysis including the taxonomic identification of the revealed helminthes and evaluation of intensity of birth infection. The birds infected with Railletina echinobothrida, (Magnin, 1881) alone were used in the studies. Later the result of biochemical tests were compared with parasitological dissection data. The significance of difference between the compared biochemical indices was evaluated using biostatistician method (Student't' test) (Matyoshichev 1990).

\section{Result}

Result of above experimental work was analyzed by using various methods. The results of parasitological analysis allowed as to divide Gallus gallus domesticus bird from natural population into four groups : i) Adult uninfected birds ii) Adult bird infected with Railletina iii) Juvenile uninfected bird and iv) Juvenile bird infected with Railletina. In blood biochemical parameter uniform trend of range was observed in plasma of infected juvenile and adult bird; albumin concentration decreased (by 20.6 and $20 \%$ respectively) while that of $\mathrm{Y}$ - 
albumins increased (by 28.3 and $112 \%$ respectively) $(p<0.05)$. Table (1) modified albumin level increased 1.4 and 1.5 fold in the plasma of adult and juvenile infected gallus gallus bird, respectively $(p<0.05)$. An increased CIC concentration was demonstrated in the plasma of juvenile (1.8 fold) and adult ( 1.7 fold) gallus bird relative to the uninfected birds $(p<0.05)$ in table- 1 . Adult infected gallus bird demonstrated a 1.4 fold increase in plasma AST activity $(p<0.05)$ table1.ALT activity and de Ritis coefficient did not significantly differ from those in intact adult animal. According to our data the level of the final product protein metabolism, urea of cretinine were similar in the plasma of infected and uninfected juvenile and adult bird (table-1). At the same time Railletina infection increased the uric acid level in both adult (1.3 fold, difference significant) and juvenile birds (1.5 fold, $\mathrm{p}<0.05)$. After experimental infection of Railletina echinobothrida, (Magnin, 1881) was detected in all experimental young birds; intensity of infestation was 26-57. The chances in protein metabolism of infected young bird were revealed 4 days after experimental infection. The increased concentration of $\alpha$-globulin (by $43.2 \%$ ), $\beta$ - globulin (by $27.4 \%$ ) modified albumin (1.8 fold) and CIC's (1.3) fold were observed $(p<0.05)$. After 8 days concentration of $\alpha$-globulin slightly decreased, the level of modified albumin $\mathrm{CIC}$ concentration controversy decreased by $22.2 \%$ relative to baseline $(p<0.05)$. After 11 days considerable changes in the protein pattern were observed in the plasma of infected nestling; the albumin level decreased (by 15\%) while the concentration of $\alpha$ globulin, $\beta$-globulin and $\gamma$-globulin increased (by $59.4 \% 52 \%$ and $27.6 \%$ respectively) $(p<0.05)$. After 14 days most plasma indices of experimental birds restored to baseline value. This applies to the level of albumin, a-globulin, $\gamma^{-}$globulin and uric acid (Table 2). At the same time the concentration of $\mathrm{CIC}$ and $\beta$ - globulin considerably increased (two fold and by $54.5 \%$ resp.) $p<0.05$.

\section{Discussion}

A typical pattern of changes in the protein composition of plasma is observed in Gallus gallus domesticus(Linn,1758) infected with cestodes parasites Railleitina echinobothrida, (Magnin, 1881) including hypoalbuminemia, hyper $\mathrm{Y}^{-}$ globulinemia and in juvenile gallus bird, hyper aglobulinemia. Similar data were obtained in studies of diphyllobothriasis in Arctic fox and gray hamster hymenolepiasis and schistosomoasis in mouse and echinococcosis in sheep (Krasov, 1969 Zulkarhev, 1975; Anikieva et, al; 1988). It was proposed that low albumin level in plasma can be due to suppresses function of the liver (where this protein is largely synthesized) by toxic metabolites of parasites (Anikieva et.al; 1988; Mazur and Propin, 2006). Changes in protein pattern of blood can be due to the effect of "nutrient withdrawal" (Ginetsinsakaya and Dobrovolshii, 1978). This can also be due to advantage for parasitic helminthes resulting from accelerated nutrient transport as repeatedly demonstrated for fish-tapeworm pairs
(Izvekova 1991, Kuzmina et.al, 2000). Y- Globulin play role in body immune response to helaminthiasis, one can propose that toxins and metabolites released by cestodes Raillietina echinobothrida (Magnin, 1881) induces antibody synthesis and general immune response in host body. As demonstrated previously the pathological process in helaminthiasis is accompanied by formation of CIC's possibly containing antibodies (Konttaninova et.al; 1998). The main function of CIC's is to remove foreign antigen from the host body. Juvenile birds have under developed immune system and are much more susceptible to the effect of parasitic antigen and toxins. High levels of $\alpha$-globulin fraction can indicate allergic reaction to parasites and stress in juvenile organism after cestodes infestation.Although cestodes Raillietina echinobothrida, is parasitic in digestive tract of birds, numerous studies demonstrated considerable functional impairments in the liver and kidney during helaminthiasis (Pathak and Gaur 1985, Rudneva et.al; 2004). Increased enzyme activities in particular AST and ALT and uric acid level in plasma of infected bird can point such changes. The experimental study demonstrated significant changes in protein metabolism in experimental gallus nestling 4 days after infestation. In particular increased level of $\alpha-$ globulin, $\beta$ - globulin modified albumin and CIC's have been demonstrated. Apparently the development of young tapeworm for four days reached the stage 'noticeable' by the host body. The fraction of $\alpha$ - globulin include the glycoprotein whose level increases in acute inflammatory and allergic reaction (Ensiklopediya Klinicheskikh 1999). Considerable changes in protein metabolism of infected nestling were observed in the period of day 8-11 of the experiment. This can be due to active metabolic activity of mature Raillietina echinobothrida, forms releasing toxic metabolites and to active antibody synthesis after exposure to foreign antigen. After 14 days, some indices of protein metabolism in plasma of infected nestling restored to baseline. Apparently, a dynamic equilibrium in the host parasite system was established at this stage. The result of protein metabolism study in Gallus gallus domesticus bird infected with cestodes Railletina echinobothrida, in the host parasite system. On the one hand, the dynamics of some indices of protein metabolism clearly confirmed negative impact on helminthes on physiological state of host. These indices primarily included the concentration of $y$ - globulin, modified albumin and CIC's. On the other hand value of many other indices in infected bird corresponds to the physiological norm. Moreover no specific pattern has been revealed in the changes in protein metabolism.

\section{Conclusion}

The inappropriate data on immune state of domestic bird with helaminthiasis to a certain extent complicates the interpretation of the obtained data. However, available data suggest a dynamic equilibrium between domestic bird and 
cestode Raillietina echinobothrida, (Magnin, 1881) at the level of protein metabolism. This equilibrium is disturbed in the period of 8-11 day after bird infestation with cestode Raillietina echinobothrida, (Magnin, 1881).

\section{Acknowledgement}

Author Mr. S.B. Waghmare is thankful to University Grants Commission for providing financial assistance through UGC-RFSMS scheme during research period.

\section{References}

[1] Izvekova G.I. (1991) Parazitologiya, 25(3), 244-248.

[2] Izvekova G.I. (2001) Parazitologiya, 35(1), 60-68.

[3] Kuklina M.M. and Kuklin V.V. (2007) Biology Bulletin, 34(5), 468-473.

[4] Kamyshnikov V.S. (2000) (Reference Book for Clinical Biochemical Diagnosis. 2 vols.), Minsk: Belarus'

[5] Krotov A.I. (1970) Med. Parazitologiya I Parazitar. Bolezni, 4, 483-491.

[6] Kuzmina V.V., Izvekova G.I. and Kuperman B.I. (2000) Usp.Sovrem. Biol., 120 (4), 384-394.

[7] Konstantinova T.N., Fillipov A.M., Ovsyannikova I.G., et al. (1998) Med.Parazitologiya I Parazitar. Bolezni, 2, 32-34.

[8] Mazur O.E. and Pronin N.M. (2006) Vopr. Ikhtiol., 46(3), 393-397.

[9] Pathak K.M.L. and Gaur S.N.S. (1985) Vet. Res. Commun., 9(2), 143-146.

[10] Troitskii G.V., Borisenko S.N. and Kasymova G.A. (1986) Lab. Delo, 4, 229-231.

[11] Zulkarnaev T.R. (1975) Med. Parazitologiya Parazitar. Bolezni, 44 (1), 78-82. 
Table 1- Biochemical indices of protein metabolism in plasma of Gallus domesticus infected with cestode $R$. echinobothrida, (Magnin, 1881)

\begin{tabular}{|l|l|l|l|l|}
\hline \multicolumn{1}{|c|}{ Index } & \multicolumn{2}{|c|}{ Adult Bird } & \multicolumn{2}{c|}{ Juvenile Bird } \\
\cline { 2 - 5 } & $\begin{array}{l}\text { Uninfected } \\
\mathrm{n}=22\end{array}$ & $\begin{array}{l}\text { Infected } \\
\mathrm{n}=23\end{array}$ & $\begin{array}{l}\text { Uninfected } \\
\mathrm{n}=17\end{array}$ & $\begin{array}{l}\text { Infected } \\
\mathrm{n}=16\end{array}$ \\
\hline Total protein, g/l & $35.8 \pm 2.5$ & $30.5 \pm 2.3$ & $31.2 \pm 2.3$ & $34.6 \pm 2.3$ \\
\hline Albumin, g/l & $20.6 \pm 1.3$ & $16.5 \pm 1.1$ & $20.4 \pm 1.3$ & $16.9 \pm 1.3$ \\
\hline a-Globulin g/l & $5.6 \pm 0.4$ & $5.3 \pm 0.6$ & $3.5 \pm 0.4$ & $4.6 \pm 0.3$ \\
\hline$\beta$ - Globulin g/l & $8.6 \pm 0.7$ & $8.0 \pm 0.6$ & $4.6 \pm 0.3$ & $4.9 \pm 0.8$ \\
\hline Y- Globulin g/l & $7.5 \pm 0.8$ & $9.7 \pm 0.9$ & $4.3 \pm 0.4$ & $9.0 \pm 1.3$ \\
\hline $\begin{array}{l}\text { Modified Albumin;\% of } \\
\text { total protein }\end{array}$ & $23.5 \pm 1.2$ & $35.4 \pm 2.5$ & $21 \pm 2.5$ & $37 \pm 3.5$ \\
\hline CIC, OD. & $36.8 \pm 3.9$ & $64.5 \pm 8.5$ & $63 \pm 4.6$ & $115 \pm 8.5$ \\
\hline ALT activity, mmol/(h1) & $0.57 \pm 0.05$ & $0.6 \pm 0.12$ & $0.59 \pm 0.03$ & $0.68 \pm 0.2$ \\
\hline AST activity, mmol/(h1) & $1.0 \pm 0.2$ & $1.3 \pm 0.2$ & $0.85 \pm 0.1$ & $1.4 \pm 0.14$ \\
\hline De Ritis Coefficients & $1.6 \pm 0.2$ & $2.0 \pm 0.18$ & $1.7 \pm 0.5$ & $1.5 \pm 0.4$ \\
\hline Urea. Mm & $0.85 \pm 0.1$ & $1.1 \pm 0.2$ & $3.6 \pm 1.5$ & $3.4 \pm 1.2$ \\
\hline Uric acid mM. & $56.8 \pm 3.5$ & $40.5 \pm 5.3$ & $0.7 \pm 0.2$ & $1.3 \pm 0.2$ \\
\hline
\end{tabular}

Table 2- Biochemical indices of protein metabolism in plasma of Gallus domesticus nestling after experimental infestation with cestode R. echinobothrida, (Magnin, 1881)

\begin{tabular}{|c|c|c|c|c|c|c|}
\hline \multirow[t]{2}{*}{ Index } & \multirow[t]{2}{*}{ Variant } & \multicolumn{5}{|c|}{ Duration Of Experiment Days } \\
\hline & & 1 & 4 & 8 & 11 & 14 \\
\hline \multirow{2}{*}{$\begin{array}{l}\text { Total protein } \\
\text { g/l }\end{array}$} & Experimental & $27.4 \pm 0.5$ & $29.3 \pm 0.3$ & $29.2 \pm 0.4$ & $31.9 \pm 0.6$ & $32.8 \pm 0.4$ \\
\hline & Control & $27.3 \pm 0.3$ & $28.4 \pm 0.2$ & $28.4 \pm 0.3$ & $28.4 \pm 0.2$ & $29.4 \pm 0.3$ \\
\hline \multirow[t]{2}{*}{ Albumin g/l } & Experimental & $14.5 \pm 0.2$ & $13.5 \pm 0.6$ & $14.6 \pm 0.5$ & $12.8 \pm 0.3$ & $15.2 \pm 0.5$ \\
\hline & Control & $15.1 \pm 0.13$ & $15.3 \pm 0.6$ & $16.8 \pm 0.8$ & $15.7 \pm 0.8$ & $16.5 \pm 0.5$ \\
\hline \multirow{2}{*}{$\begin{array}{l}\text { a- Globulin } \\
\text { g/l }\end{array}$} & Experimental & $3.5 \pm 0.1$ & $5.2 \pm 0.3$ & $4.1 \pm 0.6$ & $5.8 \pm 0.4$ & $4.3 \pm 0.3$ \\
\hline & Control & $3.4 \pm 0.2$ & $4.1 \pm 0.2$ & $3.5 \pm 0.2$ & $3.7 \pm 0.2$ & $3.9 \pm 0.1$ \\
\hline \multirow{2}{*}{$\begin{array}{l}\beta \text { - Globulin } \\
\mathrm{g} / \mathrm{l}\end{array}$} & Experimental & $7.2 \pm 0.4$ & $9.2 \pm 0.2$ & $9.3 \pm 0.5$ & $10.8 \pm 0.3$ & $11.1 \pm 0.3$ \\
\hline & Control & $6.5 \pm 0.3$ & $6.3 \pm 0.4$ & $7.0 \pm 0.4$ & $6.9 \pm 0.3$ & $7.1 \pm 0.2$ \\
\hline \multirow{2}{*}{$\begin{array}{l}\text { - Globulin } \\
\text { g/l }\end{array}$} & Experimental & $2.8 \pm 0.2$ & $3.2 \pm 0.3$ & $3.0 \pm 0.2$ & $2.8 \pm 0.2$ & $2.7 \pm 0.3$ \\
\hline & Control & $2.8 \pm 0.1$ & $3.1 \pm 0.2$ & $3.0 \pm 0.2$ & $2.8 \pm 0.3$ & $2.7 \pm 0.2$ \\
\hline \multirow{2}{*}{$\begin{array}{l}\text { Modified } \\
\text { Albumin;\% of } \\
\text { total Protein }\end{array}$} & Experimental & $27.3 \pm 2.3$ & $48.3 \pm 1.8$ & $48.4 \pm 1.8$ & $45.2 \pm 5.3$ & $40.0 \pm 2.3$ \\
\hline & Control & $25.8 \pm 1.7$ & $26.4 \pm 2.1$ & $22.3 \pm 2.1$ & $23.0 \pm 2.2$ & $22.1 \pm 2.0$ \\
\hline \multirow[t]{2}{*}{ CIC, O.D. } & Experimental & $71.5 \pm 5.5$ & $95 \pm 9.9$ & $112.5 \pm 9.6$ & $133 \pm 9.8$ & $143 \pm 11$ \\
\hline & Control & $63.3 \pm 5.2$ & $6.03 \pm 5.8$ & $65.2 \pm 4.2$ & $62.8 \pm 5.2$ & $70.0 \pm 6.5$ \\
\hline
\end{tabular}

